\title{
Adult Congenital Heart Diseases: Clinical Pattern, Management and Immediate Outcome in Ibn-Al-Bitar Center for Cardiac Surgery, Baghdad 2013
}

\author{
Dr. Jasim Nasir Alkhalidii ${ }^{1}$ \& Dr. Hassan Al-Farhan ${ }^{2}$ \\ ${ }^{1}$ M.B.Ch.B. C.A.B.P (Pediatric) \\ ${ }^{2}$ Assistant Prof. Consultant Cardiologist FICMS (Cardio), DIC, FACC, DMe
}

\begin{abstract}
:
Introduction: Adult with congenital heart diseases (ACHD) are an important emerging group. The diagnosis and successful management of congenital heart disease represents one of the greatest triumphs of cardiovascular medicine and surgery in the 20th century. As a consequence, the number of adults with congenital heart disease both with repaired and unrepaired lesions has grown rapidly.
\end{abstract}

Patients and Methods: This is a descriptive cross sectional study that conducted in Ibn Al-Bitar Center for Cardiac Surgery during the period from January 2011 to December 2012 BaghdadIraq. In this study all adults' patients with CHD referred to Ibn Al-Bitar Center for Cardiac Surgery were recorded and evaluated to verify the pattern of ACHD in our center.

Results: A total of 789 patients, female to male ratio was 1.7:1, Acyanotic CHD constitute $92.9 \%$, and whereas the cyanotic lesions form only $7.1 \%$.The mean age of patients was $29 \pm 7.300$ SD years. The most common defect was ASD followed in order of frequency by VSD, PS, TOF, PDA, AS and COA. Trans catheter intervention was the treatments of choice for many types of ACHD, but still surgery play an important role in managements of other defects.

Conclusions: Acyanotic ACHD are more common than the cyanotic one, more female predominance, Percutaneous intervention was became widely used as the first line of management of majority of ACHD with high successful rates, while surgical correction still the treatment of choice for certain types of ACHD .

Key word: Adult, congenital, heart disease, Iraq.

\section{Introduction:}

Congenital heart disease (CHD), also called congenital heart defect, includes a variety of malformations of the heart and/or its major blood vessels that are present at birth. CHD is the most common birth defect the incidence of CHD in different studies varies from about 4/1,000 to 50/1,000 live births (1). About half of these cases require medical treatment; the rest either resolve spontaneously shortly after birth or are as mild as to need no treatment or to go undetected. More than 1.4 million people with congenital heart defects were living in the United States in 2007(2). The number of adults with CHD either repaired or unrepaired lesions has grown rapidly. 
Congenital abnormalities in cardiac structure that present in subjects older than 16years, either never having been diagnosed and treated or after palliative or corrective surgery in childhood. Successful treatments for even complex congenital heart defects in childhood have resulted in increasing numbers of young adults with congenital heart disease requiring continuing surveillance and management(3). Approximately $60 \%$ of all congenital heart disease is diagnosed in babies less than one year old, 30\% in children and $10 \%$ in adults (those over 18 years of age). However, now there are more adults than children with congenital lesions and this has important implications for those practicing in any branch of adult medicine. The majority of adults with congenital heart lesions will make their way to the adult practitioner via the pediatric cardiologist (4). The population of adult CHD patients is growing at a rate of $5 \%$ per year. Survival to adulthood is better because of improved fetal diagnoses, advances in neonatal intensive care, improved surgical techniques, early complete surgical repair, lower perioperative mortality, and increased midterm and late survival. Over $85 \%$ of infants with $\mathrm{CHD}$ are now expected to reach adulthood: approximately 300,000 of these patients have complex adult CHD, 350,000 have moderately severe defects, and 350,000 have simple congenital cardiac defects (5). We have no sufficient data about adult patients with CHD. Up to our knowledge there is no national study deal with such subject. For that we conduct the study in order to define the frequency of various types of ACHD and to determine the management modalities and immediate outcome.

\section{Objectives:}

1. To define the frequency of various types of ACHD.

2. To determine the management modalities and immediate outcome.

\section{Patients and Methods:}

This is descriptive, cross-sectional study that conducted in Ibn Al-Bitar Center for Cardiac Surgery in Baghdad-Iraq during the period from January 2011 through December 2012. All cases of adult (patients more than 18 year of age) with congenital heart diseases referred to the Ibn Al-Bitar Center for Cardiac Surgery in Baghdad were included in this study.

Case Definition: are all patients with the diagnosis of CHD over 18 years of age (18, 19).

Inclusion Criteria: All cases of ACHD with diagnosis of one of the $\mathrm{CHD}$

Exclusion Criteria: That all patients with insufficient data in their files.

A pre-designed forum including name, age, sex, address, original diagnosis, types of management, whether it's medical, surgical, or Transcatheter interventions, and finally the immediate outcome is filled as it's reported. SPSS ver.19 software used for data entry and analysis. Different frequencies, percentage were calculated.

\section{Results:}

A total of 789 cases of ACHD referred to Ibn Al-Bitar Center for Cardiac Surgery, however the total number of all cases of CHD during the same period was 4442 patients. ACHD constitute about (17.76\%).The mean age of patients was 29 $\pm 7.3 \mathrm{SD}$ years, the mean age of male patients was $20 \pm 3.79$ SD years, while the 
mean age of female patients was $19 \pm 4.2$ SD years. The ages of the patients in this study range from 18-57 years, are divided into 4 major groups, as shown in table (1). Female was 499(63.2\%) patients while male 290 (36.8\%) patients, with female: male ratio is $(1.7: 1)$. It was divided according to the presence or absence of cyanosis into a cyanotic lesions 733 patients $(92.9 \%)$ and cyanotic $56(7.1 \%)$ patients figure (1). ASD account for majority of cases of adult CHD 384 patients (48.7\%) and followed in order of frequency by VSD 135 (17.1\%) patients, PS 93 (11.8\% patients), TOF 51 patients (6.5\%), PDA 47 patients (6\%), Aortic stenosis 42 patients $(5.3 \%)$, and Coaractation of aorta 32 patients $(4.1 \%)$ while complex CHD are constitute a very little number of cases, all these data are shown in table (2).

Table (1): Gender and Age Group Distribution

\begin{tabular}{|c|c|c|}
\hline Category & Frequency & Percentage \\
\hline Gender & & \\
\hline Male & 290 & $36.8 \%$ \\
\hline Female & 499 & $63.2 \%$ \\
\hline Age groups & & \\
\hline $18-27$ years & 417 & $52.9 \%$ \\
\hline $28-37$ years & 272 & $34.4 \%$ \\
\hline $38-47$ years & 93 & $11.8 \%$ \\
\hline $48-57$ years & 7 & $0.9 \%$ \\
\hline
\end{tabular}


Thi-Qar Medical Journal (TQMJ): Vol.(12), No.(2), 2016

Email:utjmed@utq.edu.iq

Web Site: https://imed.utq.edu.iq

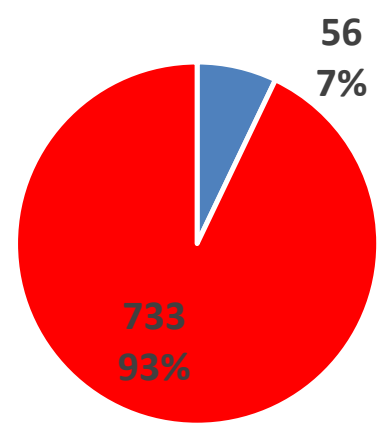

- Cyanotic acyanotic

Figure (1): ACHD Classification according to Cyanosis

Table (2): Pattern of ACHD

\begin{tabular}{|c|c|c|}
\hline Diseases & Frequency & Percentage \\
\hline ASD & 384 & 48.7 \\
\hline VSD & 135 & 17.1 \\
\hline PS & 93 & 11.8 \\
\hline TOF & 51 & 6.5 \\
\hline PDA & 47 & 6 \\
\hline $\mathbf{A S}$ & 42 & 5.3 \\
\hline COA & 32 & 4.1 \\
\hline L-TGA & 2 & 0.3 \\
\hline D-TGA & 1 & 0.1 \\
\hline DORV & 1 & 0.1 \\
\hline T A & 1 & 0.1 \\
\hline TOTAL & 789 & 100 \\
\hline
\end{tabular}


Thi-Qar Medical Journal (TQMJ): Vol.(12), No.(2), 2016

Email:utjmed@utq.edu.iq

Web Site: https://imed.utq.edu.iq

Table (3): Analysis OF ASD Managements Data

\begin{tabular}{|c|c|c|c|}
\hline $\begin{array}{c}\text { Type of } \\
\text { Treatment }\end{array}$ & $\begin{array}{c}\text { Total } \\
\text { Number }\end{array}$ & $\begin{array}{c}\text { Successful } \\
\text { Rate }\end{array}$ & $\begin{array}{c}\text { Failure } \\
\text { Rate }\end{array}$ \\
\hline $\begin{array}{c}\text { Transcatheter } \\
\text { Closure }\end{array}$ & 254 & 246 & 8 \\
\hline Surgical & $(66.1 \%)$ & $(96.9 \%)$ & $(3.1 \%)$ \\
\hline Closure & 71 & 69 & \\
\hline Medical & $(18.5 \%)$ & $(97.2 \%)$ & \\
\hline
\end{tabular}

Table (4): Surgical Treatment OF VSD, TOF and AS

\begin{tabular}{|c|c|c|c|c|}
\hline Disease & Number & Surgery & Successful & Failure \\
\hline VSD & 135 & 48 & 46 & 2 \\
\hline & & $(35.6 \%)$ & $(95.9 \%)$ & $(4.1 \%)$ \\
\hline TOF & 51 & 49 & 46 & $(6.1 \%)$ \\
\hline AS & 42 & $(96.1 \%)$ & $(93.9 \%)$ & 2 \\
& & $(83.3 \%)$ & $(94.2 \%)$ & $(5.8 \%)$ \\
\hline
\end{tabular}

Table (5): Distribution of patients with PS according to the types of treatments.

\begin{tabular}{|c|c|c|c|}
\hline Procedure & Number & Successful & Failure \\
\hline Balloon Pulmonary & 86 & 78 & 8 \\
Valvoplasty & $(92.5 \%)$ & $(90.7 \%)$ & $(9.3 \%)$ \\
\hline Medical treatment & 7 & \\
\hline
\end{tabular}


Thi-Qar Medical Journal (TQMJ): Vol.(12), No.(2), 2016

Email:utjmed@utq.edu.iq

Web Site: $\underline{\text { https://jmed.utq.edu.iq }}$

Table (6): Analysis of PDA Management's Data

\begin{tabular}{|c|c|c|}
\hline Procedures & Total & Successful \\
\hline Transcatheter Closure & 42 & 42 \\
& $(89.3 \%)$ & $(100 \%)$ \\
\hline Surgery & 2 & 2 \\
& $(4.2 \%)$ & $(4.2 \%)$ \\
\hline Medical Treatment & 3 & \\
\hline
\end{tabular}

Table (7): Modes of Management of Coaractation of aorta

\begin{tabular}{|c|c|c|c|c|}
\hline Procedure & Native & \multicolumn{2}{|c|}{ Recurrent } & Total \\
\cline { 3 - 5 } & & $\begin{array}{c}\text { Post- } \\
\text { Balloon }\end{array}$ & $\begin{array}{c}\text { Post } \\
\text { Surgery }\end{array}$ & \\
\hline Balloon & $6(18.8 \%)$ & & & $\mathbf{6}$ \\
\hline Balloon + & $14(68.8 \%)$ & $5(62.5$ & $3(37.5 \%)$ & $\mathbf{2 2}$ \\
\hline Stent & & $\%)$ & & \\
\hline Surgery & $\mathbf{4 ( 1 2 . 5 \% )}$ & & & $\mathbf{4}$ \\
\hline
\end{tabular}

\section{Managements:}

through ASD) while failed and patients referred to surgery in only 8 patients

\section{Atrial septal Defect (ASD):}

From 384 patients with ASD a Transcatheter closure was performed in 254 (66.1\%) patients, which was successful in 246 patients $(96.9 \%)$ (no significant shunt 
(3.1\%),Initial Surgical closure of ASD was performed in $71(18.55 \%)$ patients, it was successful in 69(97.2\%) patients and $2(2.8 \%)$ patients are died during the immediate post-operative period. The remaining $59(15.4 \%)$ patients with ASD are kept on medical therapy without intervention, this is shown in table (3).

\section{Ventricular septal defect (VSD):}

The frequency of adult patients with VSD was $135(17.1 \%)$ patients, from those 48 $(35.6 \%)$ patients underwent surgical closure, and it was successful in 46 (95.9\%)patients, while two (4.1\%) patients are died post operatively, the remaining 87 $(64.4 \%)$ patients are remain on medical therapy only, table (4).

\section{Pulmonary stenosis (PS):}

PS are found in 93(11.8\%) patients in our study, a trial of balloon pulmonary valvoplasty was done for 86 patients $(92.5 \%)$ which was successful in $78(90.7 \%$ ), patients (pressure gradient across the pulmonary valve decline below $36 \mathrm{mmHg}$ ) and failure of this procedure in $8(9.3 \%)$ patients, which may be due to dysplastic nature of pulmonary valve, the remaining $7(7.5 \%)$ patients are kept on medical therapy only. This is shown in table (5).

\section{Tetralogy of Fallot (TOF):}

The total number of cases of ACHD have TOF are 51 (6.5\%) patients, 49(96.1\%) patients are underwent total TOF correction with good results $(93.9 \%)$ except three (6.1\%) patients died, the other two $(3.9 \%)$ patients remain on medical therapy only table (4).

\section{Patent ductus arteriosus (PDA):}

Account for 47 (6\%) patients of adult with $\mathrm{CHD}$, attempt of transcatheter closure was done for 42 patients and it has an excellent result in all patients (no residual shunt through PDA by angiography) two (4.2\%) patients are treated by surgical ligation without complication, and the last three (6.3\%) patients are still on medical therapy, this is illustrated in table (6).

\section{Aortic stenosis (AS):}

Account for $42(5.3 \%)$ patients in our study, surgical aortic valve replacement done for 35 patients $(83.3 \%)$ and it was successful in 33 patients (94.2\%), while two (5.8\%) patients are died in the post-operative period, table (4).

\section{Coaractation of aorta (COA):}

In our study COA was found in 32 (4.1\%)patients, 22 patients $(68.8 \%)$ are treated by balloon angioplasty with stent implementation, $14(63.6 \%)$ patients of them for native COA, and eight $(36.4 \%)$ patients for recurrent COA. three $(37.5 \%)$ patients of them post-operative recurrence and five $(62.5 \%)$ patients recurrence follow balloon dilatation few years ago. Balloon angioplasty alone were attempt in six $(18.8 \%)$ patients and finally surgical treatment of COA was done in four (12.5\%) patients with good results, these data shown in table (7).

\section{Discussion:}


Adult with congenital heart diseases are an important emerging group. The modern era of surgery for CHD began 60 years ago, since then medical and surgical strategies have been devised and refined for even the most complex cardiac malformation. The spectrum of ACHD in Ibn- AlBitar Center for Cardiac Surgery emerging from this study showed that the majority of patients have atrial septal defect (ASD) followed in order of frequency by ventricular septal defect (VSD), pulmonary stenosis (PS), tetralogy of Fallot (TOF), patent ductus arteriosus (PDA), aortic valve stenosis (AS), and Coaractation of aorta (COA), the complex ACHD in our study form minority of patients, this is similar to other study done by L Shamima Sharmin, et al(27) were they found that ASD (42.6\%), VSD (18.3\%), TOF (14.8\%), PDA (7.8\%). Also other study done by Carole A. Warnes, et al (9), and also similar to studied done by Abbag, F. et al (28) and, Jia B, et al(29) and also near the study done by Rahman F, et al.(30) A.C. Zomer, et al(31) in their study they found that the mean age of adults patient with CHD is 33.1 years while in our study we found that the mean age is 29.03 years. M A Gatzoulis, et al(32) found that there was steady fall in the mean age of patients seen in clinic with time 38.5, 33.6, 31.7 year in 1987, 1992, 1997 respectively, and this is also higher than that found in our study. The mean age of female patients was lower than that of male patients this finding could be explained by the fact that female tend to consult earlier than male due to psychosocial aspect regarding marriage and pregnancy. Rahman F, et al(29) found that female patients are more than male, this figure is near the figure emerging from our study, and also from studies done by $\mathrm{P}$. Engelfriet1, et al.(33) The Acyanotic lesions form the majority of patients while the cyanotic lesion only in $7.1 \%$, this result is also compatible to studies done by Kamata K, et al.(34).

\section{Management:}

Majority of patients with ASD underwent transcatheter closure which was successful in $(96.9 \%)$ and failed in $(3.1 \%) \&$ this is similar to other studies done by Gary Webb, et al.(35), while Behjati M, et al(36) found a lower incidence of successful transcatheter closure $(89.6 \%)$ and a high failure rate $(10.4 \%)$. Surgical closure of ASD was successful in (97.2\%) with postoperative mortality rate $(2.8 \%)$, which is lower than that found in other studies done by Suchon Elzbieta, et al(37) and Chatzis A, et al(38) who showed that the mortality rate is $(0 \%)$, (1\%)respectively. Surgical closure of VSD was successful in $(95.9 \%)$ in our study, with $(4.1 \%)$ mortality rate, which is higher (mortality rate) than that found in other studies done by Naser $M$ Ammash, et al (39) Karamarie Fecho, et al (40) which reported that the operative and post-operative mortality rates was $0.8,2$, $1 \%$ respectively. Balloon pulmonary valvoplasty is the first line of management of adult patients with valvular pulmonary stenosis in our study and it was successful in $(90.7 \%)$ and failure to achieve satisfactory result in $(9.3 \%)$, which may be due to either dysplastic nature of the pulmonary valve or inefficient balloon dilatation during the procedure. This is similar to other studies done by Alan D. et al(41) Teupe C, et al(42) Lip G. et al.(43) Total correction of TOF was successful in $(93.9 \%)$ with $(6.1 \%)$ mortality rate, this result to some extent higher than that found 


\section{Email:utjmed@utq.edu.iq}

by Shahid Madani et al,(44) were found that the mortality rate is $(6.9 \%)$, while P. Engelfriet1 et al(39) and B.J.M. Mulder, et al(45) reported a lower mortality rates (3.1\%), while Abdul Razzaq Naser Hussein found in his study the overall early mortality was (24.5\%).(46) Transcatheter closure is the management of choice for patient with PDA in our study and the successful rate was encouraging (100\%), which is also compatible with result done by Eduardo E. et al(47) Ali Akbar Zeinaloo, et al(48), who found that the successful rate was (99\%) and (98.6\%) respectively. Surgical aortic valve replacement was successful in(94.2\%) and (5.8\%) post-operative mortality rate, this figure is higher than that obtained by Brad C. Astor, et al(49) and Lieberman EB, et al(50) Guerin F, et al(51) Mc Anulty JH et al(52) who found that the post-operative mortality rates are $3.5 \%, 2 \%, 1 \%$ respectively. Balloon angioplasty of Coaractation of aorta with stent implementation is the first line of management in our center which was successful in all patients (100\%), these results are also compatible to other studies done by $\mathrm{F}$ Attie, et al(53) A BuendíaHernández, et al(54) and also by Kphadke, et al.(55) Surgical repair of COA was performed in (12.5\%) without complication, while Mohammed Mahmod Saleem found that the early mortality rate following surgical repair of COA was $(5.3 \%) .(56)$.

\section{Conclusions:}

1. Simple CHD (Acyanotic) are most commonly seen in the outpatient department of adult and pediatric
Web Site: https://jmed.utq.edu.iq

cardiology, while a very low percentage of complex (cyanotic) CHD.

2. CHD in adult female are more common than male.

3. Atrial septal defect are the most common type of CHD seen in the adult population.

4. Percutaneous intervention whether transcatheter closure of certain defects or balloon dilatation of other defects was become the first line of management of many CHD in adults with high successful rates.

5. Still surgical correction is the treatment of choice for many types of CHD in adult.

\section{Recommendations:}

ACHD need more focus attention, conduct more prospective study, registry and long term follow up, preferably to be done in specialized center for ACHD

\section{References:}

1- Hoffman JIE, Kaplan S. The incidence of congenital heart disease. Journal of the American College of Cardiology. 2002;39(12):1890-900.

2- Catherine L. Webb, Kathy J. Jenkins, Peter P. Karpawich, et al, Collaborative Care for Adults With Congenital Heart Disease Barst and the Congenital Cardiac Defects Committee of the American Heart Association Section on Cardiovascular Disease in the Young. Circulation.2002; 105: 2318-2323doi: 10.1161/01.CIR.0000017557 .24261.A7.

3- Peter Engelfriet, Eric Boersma, Erwin Oechslin, et al,The spectrum of adult congenital heart disease in Europe: morbidity and 


\section{Email:utjmed@utq.edu.iq}

mortality in a five year follow-up period. The Euro Heart Survey on adult congenital heart disease. Eur Heart J. 2005 Nov; 26(21):232533. Epub $2005 \mathrm{Jul} 4$

4- Michael A, Gatzoulis, Swan Lorna et al,Adult Congenital HeartDisease,A practical guide, Department of Cardiology Western In remarry Glasgow, UK Judith Therrien Sir M. Davis Jewish General HospitalMcGill University Montreal, Quebec, Canada George A. Pantely.2005.

5- Douglas Moodie, D, M, Joseph S. Coselli, MD,Adult congenital heart diseases, Past, Present, and Future. Texas Heart Institute J. 2011; 38(6): 705-706. Bethesda MD, 20894 USA

6- Allen, Hugh D. Driscoll, David J. Shaddy et al, Moss and Adams' Heart Disease in Infants, Children, and Adolescents: Including the Fetus and Young Adults. Lippincott Williams \& Wilkins, 2008 - Medical - 1680 pages Established since 1968 as a classic pediatric cardiology text

7- Carole A. Warnes, MD, MRCP, FACC Rochester, Minnesota The Adult with Congenital Heart Disease Born to Be Bad? Journal of the Americam Collage of Cardiology JACC, Copyright (C) 2005 American College of Cardiology Foundation. Published by Elsevier Inc. Copyright (C) 2013 Elsevier B.V. July 2005, Pages 1-8.

8- J Am Coll,American College of Cardiology. Care of the adult with congenital heart disease. Presented at the 32nd Bethesda Conference, Bethesda, Maryland, 2-3 October 2000 Cardiol 2001;37:1161-1198.

9- Gary D. Webb MD, Piers E. F. Daubeney MA MRCP MRCPCH.Diagnosis and Management of Adult Congenital Heart Disease.pages528 Copyright 2011. Copyright (C) 2013.

10-Richard Liberthson, Carole A. Warnes, MD, FACC, Co-Chair, et al,The Changing Profile of
Congenital Heart Disease in Adult Life. 2001 Apr;37(5):1170-5. J Am Coll Cardiol. 2001.

11-Yusuf Karamermer and Jolien W RoosHesselink,Pregnancy and adult congenital heart disease. Future Cardiol. 2007;3(5):559-567. 2007 Future Medicine Ltd. Posted 10/29/2007

12-Professor Philip J. Steer. Pregnancy and Contraception Adult Congenital Heart Disease, A practical guide, Department of Cardio logy Western In remarry Glasgow, UK Judith Therrien Sir M. Davis Jewish General Hospital McGill University Montreal, Quebec, Canada George A. Pantely.2005.Academic Department of Obstetrics and Gynaecology, Chelsea andWestminster Hospital \& Faculty of Medicine, Imperial College, London, UK. BMJ. 2006 February 18; 332(7538): 401-406.doi: 10.1136/bmj.332.7538.401

13-Presbitero. J Somerville, E Aruta. D, Spiegelhalter, et al,Pregnancy in cyanotic congenital heart disease. Outcome of mother and fetus.Grown-Up Congenital Heart Unit, Royal Brompton National Heart and Lung Hospital, London, UK. June 2007, Pages 23032311.

14-Therrien J, Gatzoulis M, Graham T, et al Consensus Conference 2001update: Recommendations for the management of adults with congenital heart disease. Part II. Can JCardiol 2001.

15-Landzberg MJ, Murphy DJ Jr, Davidson WR Jr, et al. Task force4: organization of delivery systems for adults with congenital heart disease. J Am Coll Cardiol 2001;37(5):1187-9.

16-Harris L, Balaji S. adult with congenital heart disease. In :Gatzoulis MA, Webb GD, Daubeney PEF, eds. Diagnosis and Management of Adult Congenital Heart Disease. London: Churchill Livingstone, 2003.

17-Li W, Somerville J. Infective endocarditis in the grown-up congenital heart (GUCH) population. Eur. Heart J 1998; 19:166-173. 
Thi-Qar Medical Journal (TQMJ): Vol.(12), No.(2), 2016

18-Therrien J, Dore A, Gersony W, Iserin L, et al CCS Consensus Conference 2001 update: recommendations for the management of adults with congenital heart disease. Part I. Can J Cardiol 2001.

19-Philip Moons, Kristien Van Deyk, Kristel Marquet,et al,Individual quality of life in adults with congenital heart disease: a paradigm shift. European Heart Journal (impact factor: 10.48). 03/2005; 26(3):298-307.

DOI:10.1093/eurheartj/ehi054.

20-Douglas Moodie, Nature Clinical Practice Cardio vascular Medicine New challenges and opportunities in adult congenital heart disease.(2005) 2, 373doi:10.1038/cardio0275

21-L Shamima Sharmin, M Azizul Haque, M Iqbal Bari, Pattern and Clinical Profile of Adult Congenital Heart Disease in A Teaching Hospital prospective study conducted in the Rajshahi Medical College. Published in 2008.TAJ:Journal of teachers association. Vol 21, No 1 (2008)

22-Abbag F,Pattern of CHD in Saudi Arabia, (Dept. of Child Health,Coll. of Medicine, King Saud Univ, Abha (Saudi Arabia). Ann Saudi Med 1998;18(5):393-395.

23-Zhao QM, Ma XJ, Jia B, Huang GY et al,Prevalence of congenital heart disease at live birth:an accurate assessment by echocardiographic screening.Hospital of Fudan University, Shanghai, China. 2013 Jan 25. doi: 10.1111/apa.12170. [Epub ahead of print]. 2013 The Author(s)/Acta Paediatrica (C2013 Foundation Acta Paediatrica.

24-Rahman F, Salman M, Akhter N, Patwary SRet al,Pattern of congenital heart diseases in adult. 2012 Apr;21(2):246-50. PMID:22561766 PubMed - indexed for MEDLINE]

25-A.C. Zomer, MD; C.L. Verheugt, MD, PhD; I. Vaartjes, $\mathrm{PhD}$ C.S.P.M. Uiterwaal, et al,Congenital Heart Disease Surgery in Adults With Congenital Heart Disease. 2011 Nov 15;124(20):2195-201.

doi:
10.1161/CIRCULATIONAHA.111.027763. Epub 2011 Oct 10.

26-S Hechter, S C Siu, G D Webb,et al, Outpatient clinics for adults with congenital heart disease: increasing workload and evolving patterns of referral. Heart. 1999 January; 81(1): 57-61. 8600 Rockville Pike, Bethesda MD, 20894 USA.

27-Gary Webb, MD; P. Engelfriet1 and B.J.M. Mulder et al. Congenital Heart Disease for the Adult Cardiologist, Atrial Septal Defects in the Adult Recent Progress and Overview. Circulation.2006; 114: 1645-1653doi: 10.1161/CIRCULATIONAHA.105.592055.

28-Abe T, Kamata K, Taguchi A, Sugimoto S, Kawashima T, Inoue $S$, et al,Surgical treatment and long-term results of congenital heart disease in adults: early and late follow-up studies in 231 cases. Author: Larry W Markham, MD; Chief Editor: Park W Willis IV, MD. 1994 Jun;14(3):224-34. 8600 Rockville Pike, Bethesda MD, 20894 USA.

29-Behjati M, Rafiei M, Soltani MH et al, Transcatheter closure of atrial septal defect with amplatzer septal occluder in adults: immediate, short, and intermediate-term results. Afshar Hospital,Shahid Sadoughi University of Medical Sciences, Yazd, Iran.The Journal of Tehran Heart Center 2011. J Tehran Heart Cent. 2011 Spring; 6(2): 79-84.Published online 2011 May 31.

30-Suchon Elzbieta, Pieculewicz Monika, Tracz Wieslawa,et al, Transcatheter closure as an alternative and equivalent method to the surgical treatment of atrial septal defect in adults: Comparison of early and late result. Med Sci Monit. 2009; 15(12):CR612-7 . ISSN: 1643-3750)

31-Lucian A. Durham, M.D., Ph. D. Director, Pediatric Cardiovascular Surgery Alan M. Mendelsohn, M. D. Director, Atrial Septal Defects: Surgical and Transcatheter Management, Pediatric Interventional 
Thi-Qar Medical Journal (TQMJ): Vol.(12), No.(2), 2016

\section{Email:utjmed@utq.edu.iq}

Cardiology Strong Children's Heart Center University of Rochester Medical Center. Edited by: Mona Barmash Animation: KuoScientific GraphicsGraphic: Reprinted with permission from the Pediatric Cardiac Catheterization Laboratory, University of California, San Francisco Posted: December 17, 1998Updated: May, 2003

32-Naser M Ammash, MDHeidi M Connolly, MDSection EditorCandice Silversides, et al Ventricular septal defect in adults. Literature review current through: Jun 2013. | This topic last updated: Oct 26, 2012.

33-Karamarie Fecho,Anne T Lunney,Philip G Boysen, et al,Postoperative mortality after in patient surgery: Incidence and risk factors. Ther Clin Risk Manag. 2008 August; 4(4):681688.Published online 2008August.

34-Alan D. Tong, M.D, FACC Pediatric Cardiologist Cedars- Sinai Medical Center Los Angeles, CA, Pulmonic Stenosis and Balloon Valvuloplasty.Posted: May9,1997 Updated: May3,2001 Edited by: Mona Barmah.

35- Teupe C, Burger W, Schrader R, et al, Balloon dilatation of valvular pulmonary stenosis in adults . in PubMed 1997 Dec;86(12):1026-32.

36-Lip G, Y. H. Singh S, P. DE Giovanni Jet al,Percutaneous balloon valvuloplasty for congenital Pulmonary valve stenosis in adults. in PubMed 1996 Jul 4;335(1):21-5. N Engl J Med.

37-Eduardo E. Chang, MD, Lisa Diethelm, MD, Joseph A. Lasky, et al, Persistent Patent Ductus Arteriosus in an Adult Section of Pulmonary Disease, Critical Care and Environmental Medicine, Tulane University. South Med J. 2001;94(3) . medscape, Lippincott Williams \& Wilkins ..

38-Early and late results of total correction of tetralogy of Fallot. Department of Cardiovascular Surgery, Cardiovascular Research Center, Shahid Madani Hospital,
Web Site: https://imed.utq.edu.iq

Tabriz University of Medical Sciences, Tabriz, Iran. Acta Med Iran. 2010 Mar-Apr;48(2):11722.

39-Erdoan HB, Bozbua N, Kayalar N, Erentu $\mathrm{V}$, Omerolu SN,et al, Long-term outcome after total correction of Tetralogy of Fallot in adolescent and adult age. J Card Surg. 2005 Mar-Apr;20(2):119-23 Bethesda MD, 20894 USA

40-Abdul Razzaq Naser Hussein, Total correction of TOF at the medical city teaching hospital, A thesis submitted to the scientific council of thoracic and cardiovascular surgery in partial fulfillments of the requirement for the fellowship of the Iraqi commission for medical specialization, supervisor Dr. Emad AL Mashat, 1994.

41-Ali Akbar Zeinaloo, MD, Seyyed Mahmoud Meraji, MD2 Keyhan Sayadpour Zanjani,et al, Device Occlusion versus Surgery for Closure of Congenital Heart Defects: Cost Issues in Iran. Received 14 February 2008; Accepted 10 April 2008.

42-Brad C. Astor, Ronald G, Kaczmarek, MD, et al,Mortality after aortic valve replacement: results from a nationally representative database. Ann Thorac Surg. 2000 Dec;70(6):1939-45.

43-Lieberman EB, Wilson JS, Harrison JK, et al, Aortic valve replacement in adults after balloon aortic valvuloplasty,Davidson CJ. Division ofCardiology, Duke University MedicalCenter,Durham,NC. Circulation (1994)Volume: 90, Issue: 5 Pt 2, Pages: II205I208PubMed: 7955254

44-Guerin F, Richaud M, Duboc D, et al Congenital valvular aortic stenosis in adults.France.European Heart Journal. Oxford JournalsMedicineEuropean Heart JournalCardio image bankValvular Medicine Cardiology Update 2013

45-McAnulty JH,Timing of surgical therapy for aortic valve stenosis. Goals of therapy. Volume 
Thi-Qar Medical Journal (TQMJ): Vol.(12), No.(2), 2016

\section{Email:utjmed@utq.edu.iq}

43, Issue 6, May-June 2001, Pages 477493Timing of Valvular Surgery

46-C Zabal, F Attie, A Buendía-Hernández, et al,The adult patient with native coarctation of the aorta:balloon angioplasty or primary stenting? Heart. 2003 January; 89(1): 77-83. Journal List Heartv.89(1); Jan 2003 PMC1767490.

47-Balloon angioplasty with or without stenting for coarctation or recoarctation of aorta in adults and children. Interventional procedures IPG74. This page was last updated: 15 May 2012Issued: July 2004 Copyright 2013 National Institute for Health and Care Excellence The National Institute for Health and Clinical Excellence (NICE) has issued full guidance to the NHS in England, Wales, Scotland and Northern Ireland on balloon angioplasty with or without stenting for coarctation or recoarctation of the aorta in adults and children.

48-Thomas J. Forbes, MD, Dennis W. Kim, MD, PHD. Comparison of Surgical, Stent,and Balloon Angioplasty, Treatment ofNative
Web Site: https://imed.utq.edu.iq

Coarctation of the AortaAn Observational Study by the CCISC(Congenital Cardiovascular Interventional Study Consortium). 2011 Dec 13;58(25):2664-74. doi: 10.1016/j.jacc.2011.08.053. J Am Coll Cardiol.

49-Mohamed A Hamdan, MBBS, Sunita Maheshwari, MD, John T Fahey, MD, FACC, William E Hellenbrand, MD, FACC. Endovascular stents for coarctation of the aorta: initial results and intermediate-term follow-up. 2001 Nov 1;38(5):1518-23. J Am Coll Cardiol. PubMed. Bethesda MD, 20894 USA.

50-Mohammed Mahmod Saleem,Coaractation of aorta, A thesis submitted to the scientific council of thoracic and cardiovascular surgery in partial fulfillments of the requirement for the fellowship of the Iraqi commission for medical specialization, supervisor Dr. Siddiq AL Khashab,1998. 


\section{تثوهات القلب الولادية عند البالغين ،النمط السريري، طرق المعالجة والنتائج

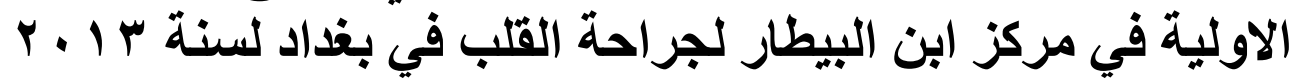 \\ جاسم ناصر عودة الخالدي \\ حسن علي الفرحان}

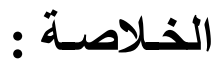

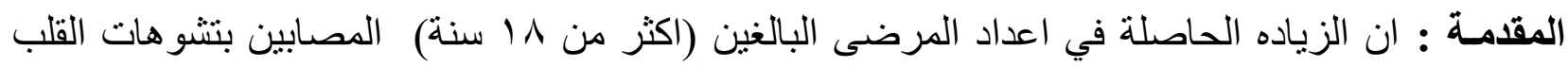

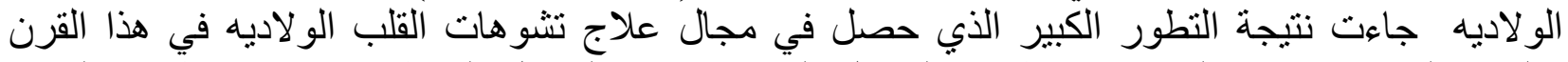

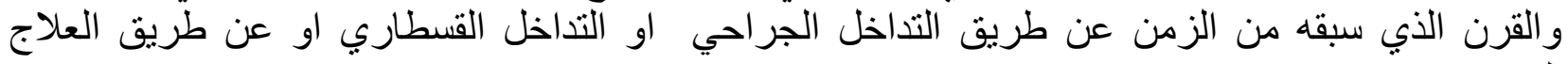
الدو ائي.

الاهداف :

- لمعرفة اعداد المرضى البالغين المصابين بتشو هات القلب الو لادية.

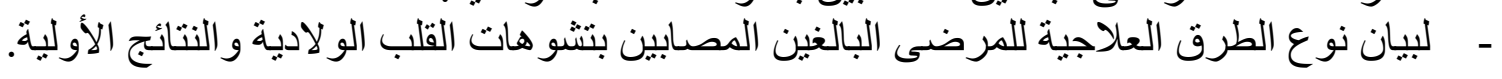

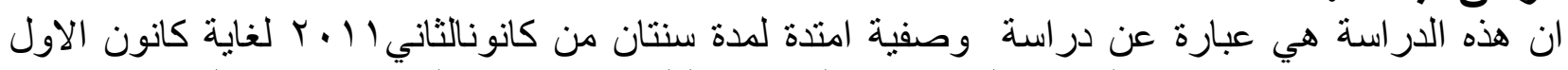

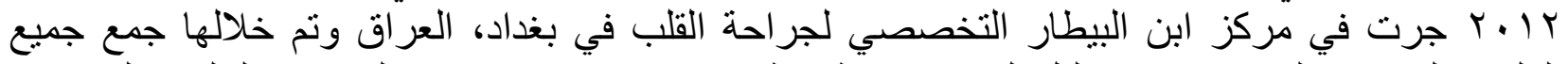

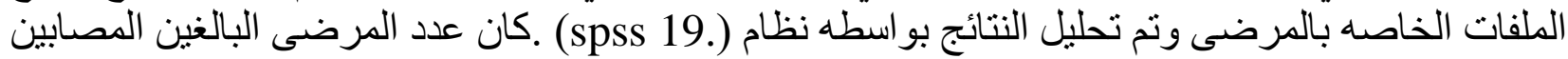

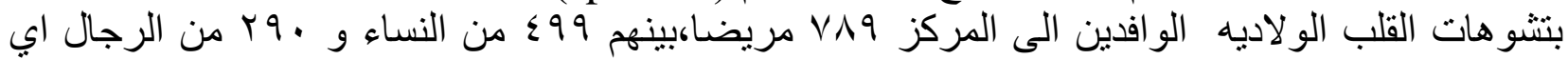

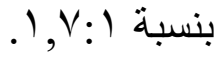

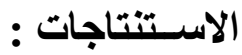

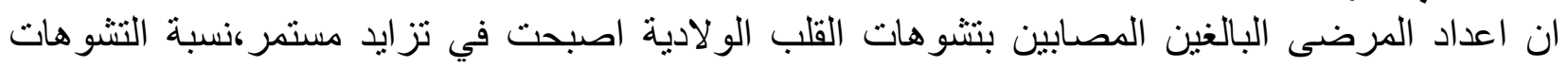

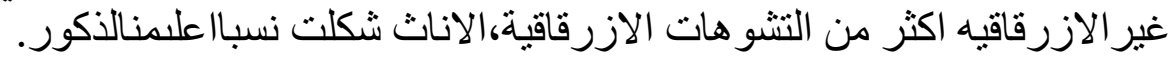

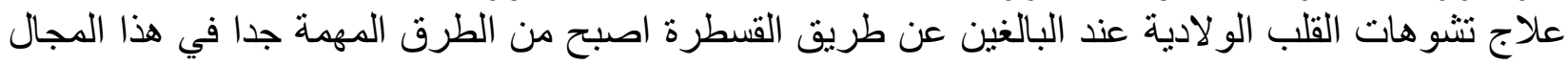
وبنسب نجاح عالية، بينما لا يز ال التداخل الجر احي يعد الخط الاول في العلاج لانو النواع الخرى من التشو هات.

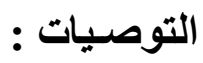

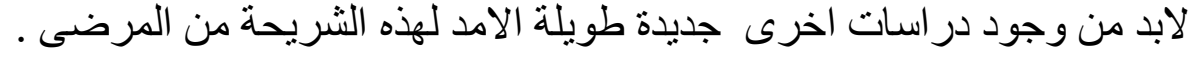

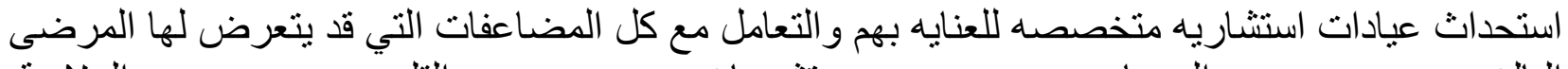
البالغين 
